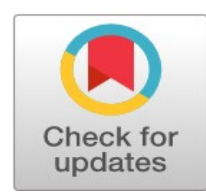

\title{
Online shopping behavior of Chinese and Japanese consumers
}

\author{
Chai Zhi-Kang ${ }^{1}$, Ikuko Ogawa ${ }^{2^{*}}$ \\ 1, 2 Graduate School of Education, Kagawa University, Kagawa, Japan
}

\author{
Keywords \\ Online shopping \\ Chinese consumer \\ Japanese consumer \\ Consumer behavior
}

Received: 7 November 2017

Accepted: 20 November 2017

Published: 4 December 2017

\begin{abstract}
Online shopping has rapidly developed all over the world. Differences of consciousness and behaviors of consumers of different countries may make consumer problems serious in cross-border net shopping. In this study, online shopping behaviors of Mainland Chinese consumers and Japanese consumers were compared. The data used for the comparison were the results of the internet survey of online shopping behaviors of Chinese and Japanese consumers collected by the Ministry of Economy, Trade and Industry of Japanese government from 2010 to 2014. Chinese consumers collected various information, and they also made a lot of inquiries and negotiations before purchasing. Nevertheless, they encountered more troubles. In those cases, they returned the goods. Much less Japanese consumers did information collection, inquiries and negotiation. They put their complaints when they encountered troubles. It was a common problem that both of them did not confirm the site security such as the location of the operator, the notation of the contact person, the responsible person, and security measure.
\end{abstract}

(C) 2017 The Author(s). Published by TAF Publishing.

\section{INTRODUCTION}

The use of consumer's online shopping is rapidly increasing all over the world. The online market in 2015 reached US $\$ 1,671$ trillion, up $25 \%$ from 2014 , and will further rise to $\$ 3,578$ trillion in 2019 (E-Marketer, 2015). Especially in China, with the rapid spread of the Internet and mobile terminals, the use of online shopping has also increased greatly. According to the survey by the China Internet Information Center (CNNIC), the Internet population of China at the end of 2014 was 649 million, the mobile Internet population using the mobile terminal reached 557 million people. (China Internet Network Information Center, 2015). It is changing from purchasing in a real shop to purchasing with net shopping in China. Actually, the market size of net shopping in China has increased more than 20 times, from 62 billion yuan in 2007 to 1.3 trillion yuan in 2012 .
(Beijing Seimochi Consulting, 2012) Consumer protection, especially consumer education is inadequate in the midst of sharp changes in consumer environments. In Japan, consumer problem of online shopping has increased considerably in 2013 according to the development of the online shopping market (Consumer Affaires Agency of Japanese Government, 2014).

Under such circumstances, net shopping is not limited to purchasing in the domestic market, and online shopping across national borders, so-called "cross-border online shopping" has also spread. In cross-border net shopping, if there is a consciousness or behavior of different consumers depending on the country, there is a possibility that it may be a big problem in cross-border net shopping if there is a problem there. Therefore, consumers who can cope with cross-border net shopping without problem, or train con-

\footnotetext{
* Corresponding author: Ikuko Ogawa

†Email: ogawa@ed.kagawa-u.ac.jp
} 
sumers who can respond to any problem and prevent it are considered important. In this research, we will clarify the characteristics from the actual behaviors of online shopping of consumers in China and Japan. From the result, we consider education for consumers who can cope with crossborder net shopping.

\section{LITERATURE REVIEW}

\section{Progress of Online Shopping and Consumers}

By 2020, over 2 billion e-shoppers, or 60 percent of target global population, would be transacting 13.5 percent of their overall retail consumptions online, equivalent to a market value of US\$3.4 trillion (Ali Research, 2016). Trust acts as a cornerstone for successful online transactions and the formation of buyer-seller relationships in e-commerce because online transactions feature high uncertainty and risks that arise from the information asymmetry between buyers and sellers (Chiu, Wang, Fang \& Huang, 2014; Pavlou \& Gefen, 2004). Many studies examined the determinants of trust and transaction risks from the buyers' perspective, assuming that buyers were placed in a disadvantaged position relative to sellers (Fang et al., 2014; Gefen, Karahanna \& Straub, 2003; Koh, Fichman \& Kraut, 2012; Pavlou, 2003; Pavlou \& Gefen, 2004; Pennington, Wilcox \& Grover, 2003). Providing a payment security net for sellers is important, which stands in sharp contrast to the view in the extant literature about the necessity to protect buyers from the opportunistic behavior of sellers. (Fang et al., 2014; Gefen et al., 2003; Koh et al., 2012; Pavlou \& Gefen 2004; Pennington et al., 2003).

\section{Progress of Online Shopping and Consumer Issues in China}

The market size of net shopping in China increased more than 20 times from 62 billion yuan to 1.3 trillion RMB in five years from 2007 to 2012 . The net growth rate of net retail price in China continues after 2013 (Beijing Seimochi Consulting, 2012). As a result, China surpassed the U.S. as the world's biggest trading nation and is a growing influence in global commerce (Bloomberg News, 2013).

The number of net shopping users in China increased from 363 million at the end of 2014 to 413 million as of December 2015 . The elongation rate was $14.3 \%$. Compared to the Internet user growth rate of $6.1 \%$ during this period, net shopping growth rate is more than twice as high. The reason for this is thought to be a result of a rapid increase in users of online shopping through smartphones (Mitsubishi UFJ Financial Group, 2016).
Meanwhile, the reasons why some Chinese Internet users did not shop online were the lack of credibility and the inconvenience of payment in the survey results of 2011 (Atsmon, Magni, Li \& Liao, 2012). Safety was still considered a big problem. However, concerning delivery anxiety and inconvenience of payment, the rate decreases year by year, giving rise to concerns about reliability, such as concerns about product quality, after-sales service, and distrust of sales sites (Kong, 2016). The China Consumers Association accepted 20,454 complaints regarding online shopping in 2012 , which accounts for $52.4 \%$ of the total number of complaints received (National People's Congress, 2013). In 2015, among more than 20,000 complaints filed by the China Consumer Association on the mail order system, Internet mail order accounts for more than 90\% (China Electronics Business Research Center, 2015).

\section{Progress of Online Shopping and Consumer Issues in Japan}

The EC market for Japanese consumer increased from 778 billion yen in 2010 to 1513.8 billion yen in 2016 to 15.1358 . This is $9.9 \%$ increase over 2015. The EC conversion rate, which is an index showing the degree of penetration of EC, also increased by 0.68 points to $5.43 \%$. However, it is lower than the US's (about 7\%) and China's (15\%). Of the total EC market, $52.9 \%$ is for merchandise-related EC, 35.4\% for service area and $11.7 \%$ for digital area (Ministry of Economy, Trade and Industry, 2016). In the Basic Survey on Consumer Awareness by Consumer Affaires Agency (2017), $43.9 \%$ of the respondents answered "online shopping" as the sales form used for products and services buying in 2016. For purposes and uses of the Internet, the ratio of using "purchase/transaction of goods/services" was 54.3\%, which was the second highest percentage after "sending and receiving e-mails" of 71\% (Ministry of Internal Affairs and Communications of Japanese Government, 2015). Gehrt, Onzo, Fujita \& Rajan (2007) surveyed Japanese webshopping environment and discovered that customers from the shopping enjoyment segment are positively inclined toward recreation, quality, and impulse orientations when making online purchase.

In these situations, the number of consumer consultations on online shopping in 2016 exceeded 250,000 (Consumer Affaires Agency, 2017). To respond to the growing cross-border online shopping, Consumer Affaires Agency established the Cross-Border Consumer Center Japan (CCJ) in 2011. The number of cross-border consumer consultations received by CCJ in 2016 was 4,473 . Of these consulta- 
tions, $98 \%$ of the consultations concerned online shopping. The location of the counterparty business was $36 \%$ from the United States, 22\% from the UK, and 9\% from China (Cross-Border Consumer Center Japan, 2017).

\section{Cross-Border Consumer Center Japan}

In 2014, the global B2C cross-border e-commerce generated transactions totaling US $\$ 230$ billion. The value will have increased to US $\$ 1$ trillion by 2020 (Erickson, 2016). Consumer perceived trust and value determine consumers' intention to shop across national borders. Consumers' perceived trust is influenced by the perception of social and formal norms in the vendor's country and by the perceived reputation of the vendor. Benefit and cost considerations determine perceived value (Huang \& Chang, 2017). Wagner, Schramm-Klein \& Schu (2016) indicated that consumers' cross-border online shopping intentions were particularly affected by the specific benefits (e.g., a wide selection and exclusive brands/products) and less so by the risks (e.g., long delivery times, additional fees, and warranty claims) of foreign online shopping. This relationship is partly moderated by foreign travelling and consumer cosmopolitanism.

Cross-border e-Commerce took over as the key growth engine to B2C trade, with a compound annual growth rate of 29.3 percent from 2014 to 2020 . Asia Pacific leads the pack, not only in overall guaranteed minimum value, but also in volume growth of cross-border e-Commerce, contributing 53.6 percent of the incremental trade volume over the period of 2014 to 2020 (Ali Research, 2016). According to the survey by the China Electronic Commerce Research Center (2015), the transaction value of the crossborder B2C market in 2014 reached 449.2 billion yuan. Of these, the value of the import cross-border B2C market accounted for 129 billion yuan. This value increased by $60 \%$ compared to 2013 . Particularly, the market size of cross-border EC for individual consumers among Japan, the United States and China has been increasing every year. In 2014, the amount purchased from overseas (imported cross border EC) was 208.8 billion yen in Japan, 813.4 billion yen in the United States, and 1235.4 billion yen in China. The market size of China as a consuming country was very large compared to Japan and the United States, and the difference between the consumption and the purchase expanded every year (Ministry of Economy, Trade and Industry, 2011, 2012, 2013, 2014). As a factor of rapid growth in China's personal import cross-border EC market, Bi (2016) pointed out the product safety issues such as foods, luxury brand orientation, expensive sales/coun- terfeit sales of overseas products, relaxation of regulations and policy support in China. Chinese consumers purchase health foods, cosmetics, pharmaceuticals with electric appliances such as electric rice cooker and automatic washing toilet seat by cross-border online shopping from Japan. As these products are necessary to purchase on a continuous basis, cross-border net shopping has expanded among Chinese consumers (Kohmura, Kamimura \& Fukushima, 2017).

There are also some studies that consumers' consciousness in each country was different about the net usage and online shopping. In a survey of comparison between American and Chinese consumers' consciousness for net shopping (Liao, Proctor \& Salvendy, 2009), Chinese consumers felt much more risk. In particular, concerns about the safety of transactions, the handling of personal information, and the after-sales service were high. It was caused from the inadequacy of infrastructure for net shopping. Regarding the net use, it was also revealed that the contents and levels of consumers' anxiety of ten countries were different (Chiba et al., 2013; Yamamoto et al., 2011; Yamamoto et al., 2012).

\section{OBJECTIVES}

Cross-border online shopping has been developing steadily. The most serious risk of cross-border online shopping was thought to be mainly related to logistics. However, as mentioned above, there were different social situations for each country and different development of the online shopping environment. And there were different tendencies of risk recognition of consumers of different countries against net and online shopping. These different situations will cause new and different risks for cross-border net consumption by consumers in each country. Regarding net consumers, many investigations have been done in the past, but the perspectives are different and detailed comparison can not be made. In this research, we decided to compare in detail the same contents of survey for several years using the results of the survey conducted for consumers in Japan, China, and the US from the survey of the Ministry of Economy, Trade and Industry.

\section{METHODOLOGY}

The data used were extracted from the report of Ministry of Economy, Trade and Industry (METI) of Japanese government, (Ministry of Economy, Trade and Industry, 2011, $2012,2013,2014,2015)$. Respondents in each survey were assigned by gender, age, and region for China. The surveys were conducted on net. In Table 1, the number of the survey respondents is listed. 
TABLE 1 . The number of the respondents of the surveys of net shopping by the MITI

\begin{tabular}{lccc}
\hline \hline Published in & Survey Conducted in & Number of Chinese Respondents & Number of Japanese Respondents \\
\hline 2011 & 2010 & 2,093 & 2,084 \\
2012 & 2011 & 2,038 & 2,070 \\
2013 & 2012 & 2,044 & 2,115 \\
2014 & 2013 & 2,000 & 2,117 \\
2015 & 2014 & 1,953 & 2,001 \\
\hline \hline
\end{tabular}

\section{RESULTS AND DISCUSSION}

\section{Recognition of Benefits and Demerits of Online Shop-} ping

In Table 2, the percentages of Chinese and Japanese respondents who agreed with the merits of net shopping were listed. The most chosen merit was "Cheaper than buying in a real store" both Chinese and Japanese, following "shopping without worrying about the travel time to the store and the opening hours of the store". Overall, Chinese consumers recognized more points as merits. They chose the merits such as "correspondence to various settlement services", "Because we can compare the functions and prices of similar products Can compare the price of the same goods", "can compare the functions and prices of similar goods", " Easy procedure and operation for purchasing goods", " and Can manage purchase history". Chinese consumers were collecting information by the functions of online shopping sites such as searching and comparing. Japanese consumers were obviously high only because of "Benefits such as points earning".

TABLE 2 . Recognition of benefits of online shopping

\begin{tabular}{|c|c|c|c|c|c|c|c|c|}
\hline & \multicolumn{4}{|c|}{ Chinese (\%) } & \multicolumn{4}{|c|}{ Japanese (\%) } \\
\hline & 2010 & 2011 & 2012 & 2013 & 2010 & 2011 & 2012 & 2013 \\
\hline & $N=1,953$ & $N=\mathbf{1 , 8 1 9}$ & $N=\mathbf{1 , 8 0 0}$ & $N=1,999$ & $N=2,001$ & $N=1,946$ & $N=1,906$ & $N=\mathbf{1 , 8 1 6}$ \\
\hline $\begin{array}{l}\text { Cheaper than buying } \\
\text { in a real store }\end{array}$ & 75.7 & 70.4 & 76.3 & 74.7 & 61.1 & 55.1 & 64.6 & 64.1 \\
\hline $\begin{array}{l}\text { Can purchase goods/services } \\
\text { that are not dealt with in real shops }\end{array}$ & 36.5 & 33.9 & 38.1 & 38.9 & 40.6 & 36.0 & 47.4 & 43.4 \\
\hline Abundant inventory/inventory check & 14.4 & 11.3 & 11.8 & 13.7 & 19.9 & 17.9 & 22.1 & 22.4 \\
\hline Can consider carefully before purchase & 38.9 & 32.4 & 37.4 & 41.1 & 33.9 & 32.0 & 35.8 & 37.9 \\
\hline $\begin{array}{l}\text { Can compare the functions and } \\
\text { prices of similar goods }\end{array}$ & 37.5 & 28.6 & 37.8 & 47.1 & 18.2 & 25.6 & 20.4 & 21.2 \\
\hline $\begin{array}{l}\text { Can compare the price } \\
\text { of the same goods }\end{array}$ & 39.4 & 33.3 & 42.1 & 46.8 & 27.5 & 23.3 & 29.2 & 28.7 \\
\hline $\begin{array}{l}\text { Can find easily the goods } \\
\text { to purchase by search function }\end{array}$ & 44.0 & 42.0 & 51.7 & 47.2 & 26.4 & 27.3 & 29.9 & 33.0 \\
\hline $\begin{array}{l}\text { Easy procedure and operation } \\
\text { for purchasing goods }\end{array}$ & 37.3 & 31.0 & 38.3 & 32.8 & 21.2 & 18.5 & 20.7 & 19.4 \\
\hline Clerk reception is not annoying & 14.4 & 11.0 & 11.2 & 17.9 & 14.4 & 15.0 & 15.3 & 13.3 \\
\hline $\begin{array}{l}\text { Correspondence to } \\
\text { various settlement services }\end{array}$ & 28.4 & 24.1 & 29.1 & 30.6 & 10.8 & 10.0 & 12.4 & 11.7 \\
\hline $\begin{array}{l}\text { Can see the evaluation/review of the } \\
\text { consumer who bought the goods }\end{array}$ & 36.7 & 31.6 & 41.7 & 50.2 & 28.4 & 21.5 & 29.4 & 27.7 \\
\hline $\begin{array}{l}\text { Can write impressions and } \\
\text { feeling of use after purchasing goods }\end{array}$ & 9.1 & 6.7 & 11.9 & 14.5 & 1.9 & 2.1 & 1.9 & 1.5 \\
\hline
\end{tabular}


Table 3 shows the recognition of the demerits of online shopping by Chinese and Japanese consumers. As a disadvantage, respondents chose the largest number in both China and Japan for "Can not check goods before purchase". Most Japanese consumers chose "Send personal information such as address and credit card number before purchase". Chinese consumers chose more for other items. They chose warranty of goods, delivery, such as "Do not know if after-sale service (returned goods, exchange, warranty, troubleshooting etc.) will be done", "Possibility of goods damage by delivery", "Possibility that the wrong product will be delivered", "Possibility that goods may not arrive even after depositing money".

TABLE 3 . Recognition of demerits of online shopping

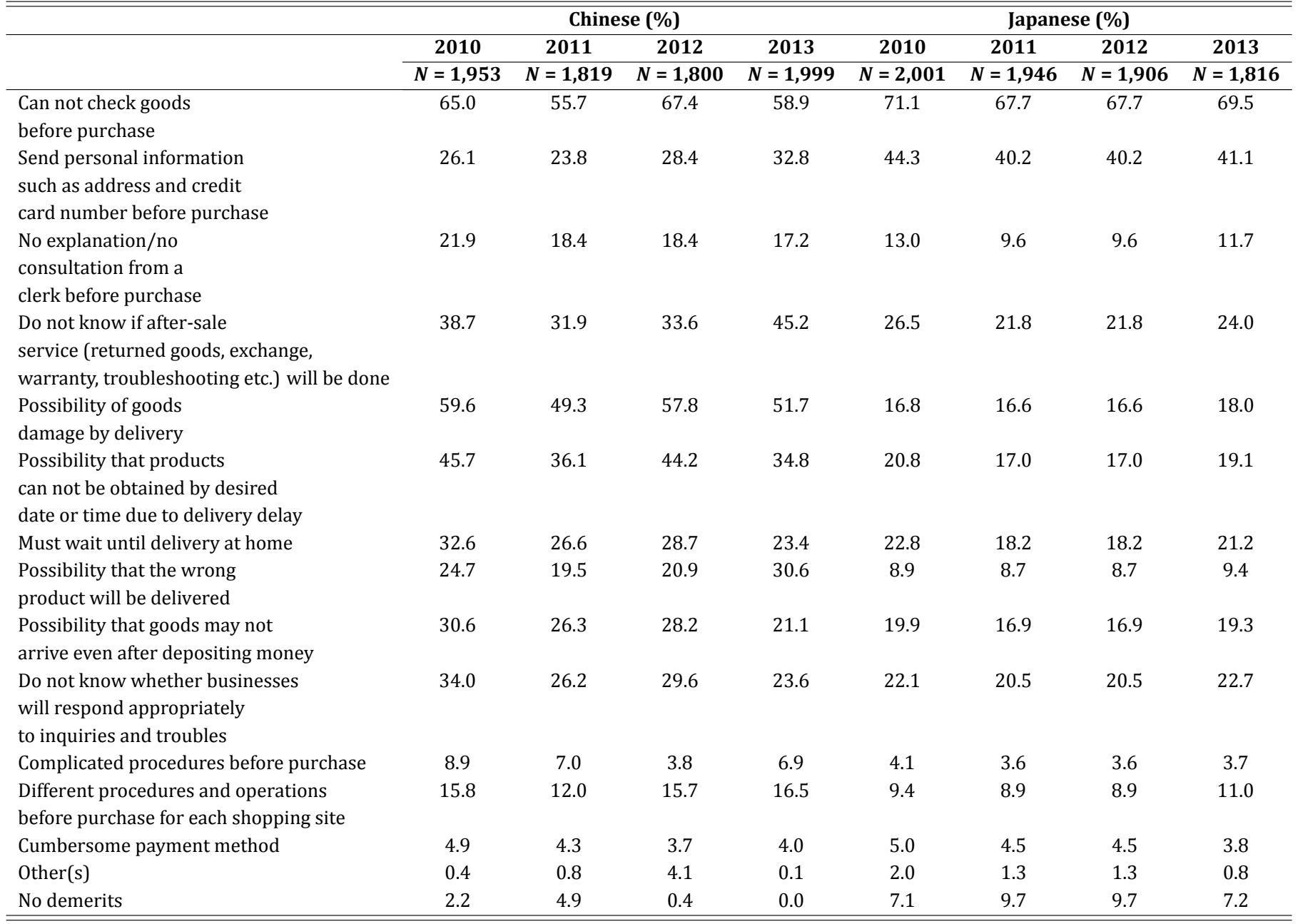

\section{Information Sharing Source for Net Shopping}

Table 4 shows the results of the information sharing sources. Chinese Consumers mostly chose more for almost all items. Japanese consumers chose more "word of mouth site(s)" only. Chinese consumers were getting information from diverse sources such as "Internet advertisement", "review site", "search result page by search engine", "home page of product provider", "and TV ad mini blog (twitter etc.)".
"Introduction from acquaintance" was particularly distinctive. Su, Xie \& Wang (2015) investigated the sources and credibility of the Internet information and reviews on China's online shopping site and revealed that they mostly trusted the accounts of their friends and relatives even in social media. It was presumed that "Introduction from acquaintance" was cited as a reliable information source. Also in Accenture's (2012) survey, 92.7\% 
of respondents answered that they utilize word information from acquaintances (family members, friends, colleagues), and $73.8 \%$ thought word information from acquaintances was "important" or "very important". Word information from acquaintances was most widely used and considered the most important one.

TABLE 4 . Information sharing source for net shopping

\begin{tabular}{|c|c|c|c|c|c|c|c|c|}
\hline & \multicolumn{4}{|c|}{ Chinese (\%) } & \multicolumn{4}{|c|}{ Japanese (\%) } \\
\hline & 2010 & 2011 & 2012 & 2013 & 2010 & 2011 & 2012 & 2013 \\
\hline & $N=1,953$ & $N=\mathbf{1 , 8 1 9}$ & $N=\mathbf{1 , 8 0 0}$ & $N=1,999$ & $N=2,001$ & $N=1,946$ & $N=1,906$ & $N=1,816$ \\
\hline TV advertisement & 35.1 & 41.9 & 39.6 & 22.4 & 11.6 & 17.7 & 17.4 & 18.5 \\
\hline Internet advertisement & 34.5 & 54.2 & 49.9 & 47.6 & 17.3 & 31.4 & 30.6 & 31.5 \\
\hline Magazine articles/newspaper articles & 22.3 & 15.6 & 16.8 & 20.3 & 10.7 & 14.2 & 12.9 & 11.5 \\
\hline Home page of product provider & 25.2 & 28.5 & 30.2 & 28.6 & 23.0 & 32.4 & 32.2 & 24.1 \\
\hline $\begin{array}{l}\text { Search result page } \\
\text { by search engine page }\end{array}$ & 27.3 & 34.7 & 9.3 & 31.2 & 20.6 & 29.6 & 32.6 & 29.7 \\
\hline E-mail magazine & 15.6 & 11.1 & 8.3 & 10.8 & 9.7 & 17.7 & 15.2 & 16.8 \\
\hline Mini blog (twitter etc.) & 13.9 & 21.3 & 20.7 & 22.8 & 2.0 & 4.1 & 4.0 & 6.1 \\
\hline SNS & 9.3 & 2.9 & 2.5 & 6.8 & 2.6 & 5.1 & 4.7 & 5.6 \\
\hline Q\&A community & 15.5 & 3.7 & 2.7 & 6.6 & 2.5 & 3.9 & 4.9 & 4.7 \\
\hline Electronic bulletin board (BBS) & 11.3 & 4.6 & 4.7 & 6.8 & 3.3 & 4.7 & 5.2 & 5.5 \\
\hline Real store & 27.9 & 24.4 & 30.0 & 22.0 & 13.8 & 17.3 & 20.5 & 14.6 \\
\hline Mail order catalog & 12.9 & 6.3 & 7.9 & 6.8 & 7.5 & 11.9 & 10.1 & 9.4 \\
\hline Exhibitions/Events & 14.4 & 8.8 & 11.7 & 11.0 & 1.7 & 1.8 & 1.7 & 1.4 \\
\hline Introduction from acquaintance & 38.3 & 37.4 & 39.2 & 37.9 & 9.1 & 11.8 & 10.5 & 10.3 \\
\hline Other(s) & 10.9 & 2.4 & 4.7 & 0.5 & 9.9 & 7.9 & 10.9 & 0.1 \\
\hline Not collect information & 4.7 & 0.3 & 0.0 & 4.0 & 0.4 & 0.1 & 0.3 & 16.5 \\
\hline
\end{tabular}

\section{Selection of Online Shopping Site}

Table 5 shows the answer results of the reasons for selecting the online shopping site. From both Chinese consumers and Japanese consumers, 60 to $70 \%$ had chosen "cheap", following "the number of goods is abundant". Chinese consumers chose "Availability of detail product information/developers' or producers' information", "Fast delivery", "Availability of purchaser's evaluation comments", "Specification of delivery date, inventory information or delivery status of purchased goods", "Sites introduced by friends/acquaintances" more than Japanese consumers. Japanese consumers chose more than Chinese consumers, "Point system" and "Past experience" only. It was presumed that China was considering from more viewpoints when selecting a shopping site.

On the other hand, the reliability of the site, such as "Clear indication of address of the business operator, con-

tact address, or person in charge", and "Security measures" ISSN: 2414-309X were selected up to only $10 \%$. Chinese and Japanese consumers did not consider these points so much for site selection.

\section{Inquiries to Online Shopping Site}

Table 6 shows the results of inquiries from Chinese consumers and Japanese consumers about their inquiries to the online shopping site. For Chinese consumers after 2011, over $60 \%$ of respondents inquire about any points. On the other hand, Japanese consumers chose "Stock and delivery date" as about $20 \%$ at maximum. Although it tends to increase little by little with respect to "Product function" and "Product specification", it is remarkably small compared to Chinese consumers.

Table 7 shows the results of asking Chinese consumers and Japanese consumers whether they had experience

negotiating prices during net shopping. The percentage

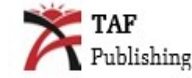


of Chinese consumers who responded that they had negotiated the price anytime was significantly higher than Japanese consumers. For Japanese consumers, it was less than $10 \%$ at maximum. Based on these results, Chinese consumers often carried out various inquiries before purchase, such as interaction with sites, checking sites, and price negotiations, more than Japanese consumers.

TABLE 5 . Reasons for selection of online shopping site

\begin{tabular}{|c|c|c|c|c|c|c|}
\hline & \multicolumn{3}{|c|}{ Chinese (\%) } & \multicolumn{3}{|c|}{ Japanese (\%) } \\
\hline & 2011 & 2012 & 2013 & 2011 & 2012 & 2013 \\
\hline Various items & 62.8 & 58.9 & 30.4 & 51.1 & 48.3 & 56.8 \\
\hline $\begin{array}{l}\text { Search or narrow } \\
\text { down products }\end{array}$ & 30.4 & 31.1 & 21.5 & 37.7 & 30.6 & 35.8 \\
\hline $\begin{array}{l}\text { Availability of detail } \\
\text { product information/developers' } \\
\text { or producers' information }\end{array}$ & 22.7 & 24.5 & 30.4 & 10.0 & 9.8 & 10.6 \\
\hline Various inventory & 12.4 & 7.3 & 18.8 & 18.4 & 16.4 & 15.7 \\
\hline Cheap price & 67.9 & 71.7 & 57.4 & 63.7 & 64.6 & 67.7 \\
\hline Fast delivery & 25.7 & 30.7 & 30.1 & 16.4 & 16.9 & 18.5 \\
\hline Point system & 12.6 & 10.8 & 13.7 & 31.8 & 28.9 & 31.2 \\
\hline $\begin{array}{l}\text { Availability of purchaser's } \\
\text { evaluation comments }\end{array}$ & 26.7 & 31.6 & 36.2 & 21.5 & 19.3 & 18.1 \\
\hline Recommendation function & 5.8 & 3.3 & 7.2 & 0.6 & 0.5 & 1.0 \\
\hline $\begin{array}{l}\text { Easy-to-understand } \\
\text { site composition }\end{array}$ & 7.4 & 6.0 & 12.4 & 4.5 & 4.1 & 5.2 \\
\hline Gift wrapping availability & 4.3 & 2.7 & 6.2 & 2.0 & 1.5 & 1.6 \\
\hline $\begin{array}{l}\text { Clear indication of address } \\
\text { of the business operator, } \\
\text { contact address, or person in charge }\end{array}$ & 9.3 & 13.7 & 11.5 & 8.0 & 7.6 & 7.2 \\
\hline $\begin{array}{l}\text { Specification of delivery date, } \\
\text { inventory information or } \\
\text { delivery status of purchased goods }\end{array}$ & 14.0 & 14.1 & 21.3 & 5.8 & 5.7 & 5.1 \\
\hline Security measures & 13.7 & 13.8 & 18.5 & 12.1 & 15.0 & 13.5 \\
\hline Various payment methods & 15.9 & 19.0 & 19.1 & 12.1 & 13.4 & 11.2 \\
\hline $\begin{array}{l}\text { Various delivery methods } \\
\text { and receiving methods }\end{array}$ & 3.6 & 3.1 & 11.7 & 5.0 & 6.2 & 4.7 \\
\hline $\begin{array}{l}\text { No shipping fee/cheap } \\
\text { shipping fee/discount shipping fee }\end{array}$ & 33.9 & 37.6 & 24.6 & 30.7 & 35.7 & 33.3 \\
\hline Major sites/famous sites & 15.7 & 16.2 & 19.9 & 18.2 & 19.8 & 20.8 \\
\hline $\begin{array}{l}\text { Sites introduced by } \\
\text { friends/acquaintances }\end{array}$ & 9.9 & 9.8 & 9.9 & 1.3 & 1.2 & 0.7 \\
\hline Careful handling & 5.3 & 4.2 & 11.6 & 4.1 & 3.7 & 3.1 \\
\hline Availability of inquiry form & 0.5 & 1.6 & 2.0 & 2.5 & 2.6 & 2.6 \\
\hline
\end{tabular}


TABLE 6. Inquiries to the online shopping site

\begin{tabular}{lcccccccc}
\hline \hline & \multicolumn{3}{c}{ Chinese (\%) } & \multicolumn{3}{c}{ Japanese (\%) } \\
\hline & $\mathbf{2 0 1 0}$ & $\mathbf{2 0 1 1}$ & $\mathbf{2 0 1 2}$ & $\mathbf{2 0 1 3}$ & $\mathbf{2 0 1 0}$ & $\mathbf{2 0 1 1}$ & $\mathbf{2 0 1 2}$ & $\mathbf{2 0 1 3}$ \\
\cline { 2 - 9 } & $\mathbf{N = \mathbf { 8 0 7 }}$ & $\mathbf{9 2 1}$ & $\mathbf{7 6 8}$ & $\mathbf{1 9 2 7}$ & $\mathbf{1 6 2 2}$ & $\mathbf{1 5 7 5}$ & $\mathbf{1 5 7 0}$ & $\mathbf{1 7 9 6}$ \\
\hline Product function & 58.0 & 86.9 & 87.9 & 85.0 & 8.8 & 15.0 & 14.2 & 17.9 \\
Product specification & 54.9 & 86.0 & 87.0 & 85.2 & 7.8 & 14.6 & 13.3 & 18.5 \\
Terms of instruction manuals & 17.6 & 65.4 & 65.1 & 67.8 & 1.1 & 5.6 & 4.2 & 8.4 \\
or operation screens of products & & & & & & & & \\
Product usage method & 31.7 & 73.2 & 76.1 & 75.0 & 2.5 & 6.7 & 4.8 & 9.3 \\
Genuine product or fake product & 44.4 & 76.7 & 79.8 & 77.1 & 1.4 & 5.6 & 4.1 & 7.3 \\
Presence of real stores & 20.2 & 63.8 & 57.4 & 61.9 & 1.4 & 5.0 & 3.6 & 7.4 \\
Stock and delivery date & 42.1 & 83.2 & 84.8 & 82.1 & 14.7 & 20.7 & 18.2 & 20.9 \\
Payment & 36.8 & 70.9 & 67.7 & 72.4 & 6.0 & 11.4 & 9.2 & 13.0 \\
Delivery trader/delivery & 32.8 & 76.3 & 74.7 & 80.2 & 5.1 & 9.8 & 7.9 & 12.5 \\
means/delivery area & & & & & & & & 11.0 \\
After-sales service & 47.5 & 83.0 & 81.1 & 82.5 & 3.9 & 9.0 & 6.9 & \\
(free warranty period etc.) & & & & & & & & 9.4 \\
Product price & 47.1 & 84.3 & 85.4 & 83.1 & 2.2 & 5.9 & 5.1 & \\
(discount availability etc.) & & & & & & & \\
\hline \hline
\end{tabular}

TABLE 7 . Price negotiation with online

\begin{tabular}{cccc}
\multicolumn{3}{c}{ shopping site } \\
\hline & Chinese (\%) & & Japanese (\%) \\
\hline 2011 & 51.3 & $>$ & 6.2 \\
2012 & 38.3 & $>$ & 1.6 \\
2013 & 69.0 & $>$ & 7.7 \\
\hline \hline
\end{tabular}

\section{Troubles with Online Shopping}

Table 8 shows the results of asking Chinese consumers and Japanese consumers about their troubles in online shopping. In 2011 and 2012, many Japanese consumers answered their troubles with "Delay of good delivery/services providing (several days to one week)", " and Product was defective or fake/Defect in service". However, these were drastically reduced in 2013. Many Chinese consumers answered "No delivery of goods/No service provided", "Did not match the product standard to the national standard", "Deformation and breakage of packing (No influence on goods)", "Deformation and breakage of packing/goods also damaged", "Different from the product on the site/the photo on the site", "Not get refund of the goods price", "Problem with shipping fee and commission (unreasonably high etc.)". Overall, Chinese consumers experienced much more troubles than Japanese consumers.

Table 9 shows the results of the complaint experience for net shopping troubles of Chinese consumers and Japanese consumers. The troubles in which many consumers com- plained were: "No arrival of goods/No service provided", "Delivery of different good(s)/Different service content(s)", "Defective or fake goods/Incomplete service", "The packaging was deformed or damaged, and the good(s) was damaged", "Different goods from the site or photos".

Japanese consumers made more complaints than Chinese consumers. For example, Japanese consumers complained "Not enough response to inquiries" or "No e-mail or late e-mail at the completion of purchase" much more than Chinese consumers.

Taking into consideration the result in Table 6, Japanese consumers seldom inquire before the purchase, but are found asking for a sufficient response when a trouble happens. Chinese consumers made various inquiries before purchasing, but even when they are still in trouble, they did not make much complaint.

Table 10 shows the percentage of people who returned the product(s) when troubleshooting online shopping. About $20 \%$ of Japanese consumers returned. More Chinese consumers returned every year, exceeding $60 \%$ 
in 2013. Many Chinese consumers made various inquiries before purchasing, but still in trouble, they made no complaints, but returned product(s). Based on these results, it was clear that Chinese consumers and Japanese consumers have different consciousness about net shopping due to different social situation, different behaviors to avoid net shopping troubles, and different behaviors with net shopping troubles.

TABLE 8 . Claim against problems to net shopping site

\begin{tabular}{|c|c|c|c|c|c|c|}
\hline & \multicolumn{3}{|c|}{ Chinese (\%) } & \multicolumn{3}{|c|}{ Japanese (\%) } \\
\hline & 2011 & 2012 & 2013 & 2011 & 2012 & 2013 \\
\hline $\begin{array}{l}\text { No arrival of goods/No } \\
\text { service provided }\end{array}$ & 60.2 & 50.3 & 43.9 & 87.5 & 54.2 & 71.4 \\
\hline $\begin{array}{l}\text { Delivery of different good(s)/Different } \\
\text { service content(s) }\end{array}$ & 60.5 & 44.8 & 45.3 & 82.9 & 54.5 & 79.6 \\
\hline $\begin{array}{l}\text { Defective or fake goods/ } \\
\text { Incomplete service }\end{array}$ & 72.4 & 54.3 & 45.9 & 89.5 & 61.8 & 81.6 \\
\hline $\begin{array}{l}\text { The prod } \\
\text { match th }\end{array}$ & 45.2 & 44.7 & 42.2 & 50.0 & 22.2 & 46.7 \\
\hline $\begin{array}{l}\text { Delay in products delivery } \\
\text { or providing services } \\
\text { (several days to one week) }\end{array}$ & 61.1 & 41.4 & 27.5 & 71.9 & 30.3 & 32.0 \\
\hline $\begin{array}{l}\text { Delay in products delivery } \\
\text { or providing services } \\
\text { (a few weeks or more) }\end{array}$ & 76.4 & 44.6 & 42.2 & 77.6 & 47.1 & 55.7 \\
\hline $\begin{array}{l}\text { The packaging was deformed } \\
\text { or damaged (no impact on products) }\end{array}$ & 45.7 & 43.9 & 24.3 & 36.4 & 20.8 & 23.4 \\
\hline $\begin{array}{l}\text { The packaging was deformed or } \\
\text { damaged, and the good(s) was damaged }\end{array}$ & 69.1 & 56.6 & 50.3 & 80.4 & 80.0 & 70.4 \\
\hline $\begin{array}{l}\text { Different goods from } \\
\text { the site or photos }\end{array}$ & 64.3 & 53.4 & 35.7 & 52.5 & 60.0 & 54.5 \\
\hline $\begin{array}{l}\text { No product or insufficient } \\
\text { numbers of goods }\end{array}$ & 56.9 & 42.0 & 41.3 & 2.9 & 80.0 & 76.9 \\
\hline $\begin{array}{l}\text { Unable to cancel or } \\
\text { return the item }\end{array}$ & 44.1 & 41.2 & 32.7 & 53.1 & 50.0 & 52.2 \\
\hline No refund of the goo & 46.2 & 28.7 & 34.5 & 60.0 & 40.0 & 40.0 \\
\hline $\begin{array}{l}\text { Problem with shipping fee } \\
\text { and commission (unreasonably high etc.) }\end{array}$ & 37.3 & 28.7 & 21.8 & 50.0 & 25.0 & 50.0 \\
\hline Problem with request for goods price & 26.1 & 34.0 & 16.7 & 100.0 & 66.7 & 70.0 \\
\hline $\begin{array}{l}\text { Inadequate Product } \\
\text { warranty (content or period) }\end{array}$ & 56.0 & 37.4 & 21.9 & 15.4 & 57.1 & 28.6 \\
\hline $\begin{array}{l}\text { Increase of phones or spam } \\
\text { mails from unknown people after ordering }\end{array}$ & 32.4 & 30.6 & 16.7 & 32.1 & 0.0 & 7.7 \\
\hline $\begin{array}{l}\text { No e-mail or late e-mail at } \\
\text { the completion of purchase }\end{array}$ & 44.4 & 28.6 & 15.6 & 46.9 & 57.1 & 20.4 \\
\hline No enough response to inquiries & 29.8 & 19.6 & 15.0 & 46.7 & 71.4 & 53.5 \\
\hline
\end{tabular}

Percentage of the number of people actually putting complaints against the number of people who encountered trouble

TABLE 9 . Experience of goods return to net shopping site

\begin{tabular}{lcc}
\hline \hline & Chinese (\%) & Japanese (\%) \\
\hline 2010 & 35.4 & 19.5 \\
2011 & 43.5 & 26.0 \\
2012 & 45.7 & 22.2 \\
2013 & 62.3 & 23.3 \\
\hline \hline
\end{tabular}




\section{CONCLUSION}

Consumers' awareness of online shopping might be different for each country, depending on the different social situation and the development history of the online shopping environment. This will cause new and greater risks for consumers for cross-border online shopping. From the results of the survey conducted continuously for Chinese and Japanese for several years of METI, the comparison of awareness of online shopping between Chinese consumers and Japanese consumers was made.

As a result, online shopping was used for the convenience of price, travel time, and business hours by Chinese consumers and Japanese consumers. However, for Chinese consumers the easiness of information gathering such as searching and comparison was also the reason for using online shopping. Regarding disadvantage recognition, Japanese consumers were concerned about the transmission of personal information, but Chinese consumers had more anxiety of product warranty and delivery.

Chinese consumers collected information on online shopping through various media. Regarding the reason for choosing the site to use, both Chinese consumers and Japanese consumers chose prices, and abundant product numbers in common. Chinese consumers had selected sites from more viewpoints, such as buyer's comment on evaluation, delivery date/inventory information, delivery situation, and introduction from friends/acquaintances. Chinese consumers as low as $60 \%$ responded that they will contact the site and about $20 \%$ from the Japanese consumers. The rate of negotiating prices is also significantly higher for Chinese consumers than for Japanese consumers. On the other hand, Chinese consumers have more trouble experience than Japanese consumers. When experiencing trouble, Japanese consumer claims are often experienced. Experience in re- turning goods when encountering trouble is high in Chinese consumers.

From the results, it was clear that there were common situations and different situations between Chinese consumers and Japanese consumers. Chinese consumers collected various information, and also made inquiries and negotiations before purchasing. Still, the rate of encountering trouble was high. They deal with returning goods in those case. Japanese consumers did not collect information, inquire or negotiate much before purchasing. They complained when they got into troubles.

For both consumers, they did not take into consideration information related to the reliability of the site for selection of the shopping site, such as "the location of the business operator, the contact address and the responsible person clearly indicated", "and the security measures are being done".

This was one of the big common problems for Chinese and Japanese consumers. Cross-border net shopping is expected to increase more and more in the future. Knowing consumers themselves about the characteristics of their behaviors would be the key to preventing serious consumer problems in cross border online shopping. Furthermore, consumer education to enable necessary recognition and action, such as security confirmation, for healthy consumption will be necessary for consumers in any country.

\section{LIMITATIONS}

The actual situation of consumers' use of the net changes intensely. The sense of net and net shopping is remarkably different depending on generation. Therefore, it is unknown when the results of this research are effective. However, the risk of net shopping does not always proceed in a direction to be alleviated. As the fact that there were differences in consciousness and reality by country and region is important, this research might be meaningful.

\section{REFERENCES}

Accenture. 2012. Accenture investor \& analyst. URL: goo.gl/cAkWoD. Last accessed on 12 January 2016. Ali Research. 2016. Global cross border B2C e-commerce Market 2020: Report highlights \& methodology sharing.

URL: goo.gl/eHrEs2. Last accessed on 14 March 2016.

Atsmon, Y., Magni, M., Li, L., \& Liao, W. 2012. Meet the 2020 Chinese consumer. URL: goo.gl/S3RXj2. Last accessed on 21 July 2017.

Beijing Seimochi Consulting. 2012.Report of mobile internet survey in China. URL: goo.gl/jbdTe6. Last accessed on 7 $\mathrm{Au}-$ gust 2017.

Bi, C.L. 2016. Analysis and forecast of trends of imported cross-border EC market for consumers study on the Chinese mar- $\quad$ ket. Research Society of Commerce and Economics, 56(2): 35-65. 
Bloomberg News. 2013. China eclipses U.S as biggest trading nation. URL: goo.gl/Ld3hdf. Last accessed on 20 August 2016.

Cross-Border Consumer Center Japan. 2017. Outline of cross-border consumer counseling in fiscal year 2016-consultation accepted at the cross-border consumer center. URL: goo.gl/JFzm9o. Last accessed on 19 ASeptember 2016.

Chiba, N., Yamamoto, T., Seki, Y., Takahashi, K., Ogasahara, M., Sekiya, N., Nakamura, I. \& Hashimoto, Y. 2013. International comparative study of users' awareness to harmful information on the internet. Information Processing Society of Japan Journal, 54: 1619-1631. DOI: 10.2197/ipsjjip.19.212

China Electronics Business Research Center. 2015. Report on monitoring of complaints in China's e-commerce. URL: goo.gl/kh88nX. Last accessed on 10 October 2016.

Chiu, C.M., Wang, E.T., Fang, Y.H., \& Huang, H.Y. 2014. Understanding customers' repeat purchase intentions in B2C e-commerce: The roles of utilitarian value, hedonic value and perceived risk. Information Systems Journal, 24(1): 85-114.

DOI: $10.1111 / \mathrm{j} .1365-2575.2012 .00407 . x$

China Internet Network Information Center. 2015. Statistical report on internet development in China 2015.

URL: goo.gl/mFvC3x. Last accessed on 15 June 2016.

Consumer Affaires Agency. 2017. Basic survey of consumer awareness 2017. URL: goo.gl/hwW8Su. Last accessed on 20 March 2016.

Consumer Affaires Agency of Government of Japan. 2014. Basic survey of consumer awareness 2014. URL: goo.gl/hwW8Su. Last accessed on 20 March 2016.

E-Marketer. 2015. Worldwide retail ecommerce sales: emarketer's updated estimates and forecast through 2019. URL: goo.gl/KQJNfF. Last accessed on 26 February 2016.

Erickson, J. 2016. Cross-border e-commerce to reach \$1 trillion in 2020. URL: goo.gl/R91JGi. Last accessed on 15 Septem2016.

Fang, Y., Qureshi, I., Sun, H., McCole, P., Ramsey, E., \& Lim, K.H. 2014. Trust, satisfaction, and online repurchase intention: The moderating role of perceived effectiveness of e-commerce institutional mechanisms. MIS Quarterly, 38(2):

407- 427. DOI: 10.25300/misq/2014/38.2.04

Gefen, D., Karahanna, E., \& Straub, D.W. 2003. Trust and TAM in online shopping: An integrated model. MIS Quarterly, 27(1): 51-90. DOI: $10.2307 / 30036519$

Gehrt, K.C., Onzo, N., Fujita, K., \& Rajan, M.N. 2007. The emergence of Internet shopping in Japan: Identification of shop- ping orientation-defined segments. Journal of Marketing Theory and Practice, 15(2): 167-177.

DOI: $0.2753 / \mathrm{mtp} 1069-6679150206$

Huang, S.L., \& Chang, Y.C. 2017. Factors that impact consumers' intention to shop on foreign online stores. Paper pre- $\quad$ sented in the Proceedings of the $50^{\text {th }}$ Hawaii International Conference on System Sciences, Hawaii, HI.

DOI: $10.24251 /$ hicss.2017.481

Koh, T.K., Fichman, M., \& Kraut, R. 2012. Trust across borders: Buyer-supplier trust in global B2B e-commerce. Journal of the Association for Information Systems, 13(11): 887-922. D0I: 10.5465/ambpp.2009.44243458

Kohmura, T., Kamimura, S., \& Fukushima, K. 2017. Study on supply Chain for promoting cross-the-border e-commerce of Japanese products toward Chinese consumer market. Josai Contemporary Policies Researches, 10(1): 65-70.

Kong, L. 2016. Actual condition and problems of Internet mail order sales in China. Kanagawa University Asian Review, 3: 56-67.

Liao, H., Proctor, R.W., \& Salvendy, G. 2009. Chinese and US online consumers' preferences for content of e-commerce web- $\quad$ sites: A survey. Theoretical Issues in Ergonomics Science, 10(1): 19-42. D0I: 10.1080/14639220801936588 Ministry of Economy, Trade and Industry. 2011. Report of infrastructure development of information economic society in Japan, Market research on e-commerce. URL: goo.gl/xRKuQF. Last accessed on 21 May 2016.

Ministry of Economy, Trade and Industry. 2012. Report of infrastructure development of information economic society in Japan, Market research on e-commerce. URL: goo.gl/m1uGJW. Last accessed on 10 June 2016.

Ministry of Economy, Trade and Industry. 2013. Report of infrastructure development of information economic society in Japan, Market research on e-commerce. URL: goo.gl/JW4PaU. Last accessed on 18 July 2016. 
Ministry of Economy, Trade and Industry. 2014. Report of infrastructure development of information economic soci- ety in Japan, Market research on e-commerce. URL: goo.gl/qM7cv9. Last accessed on 25 August 2016.

Ministry of Economy, Trade and Industry. 2015. Report of infrastructure development of information economic society

in Japan, Market research on e-commerce. URL: goo.gl/RpLnsM. Last accessed on 15 September 2016.

Ministry of Economy, Trade and Industry. 2016. Report of infrastructure development of information economic society

in Japan, Market research on e-commerce. URL: goo.gl/KnErFF. Last accessed on 15 February 2017.

Ministry of Internal Affairs and Communications of Japanese Government. 2015. Survey on trend of communication use.

URL: goo.gl/SN4atK. Last accessed on 21 February 2016.

Mitsubishi UFJ Financial Group. 2016. MUFGBTMU (China) report of market research of net shopping 2015.

URL: goo.gl/e8aeyN. Last accessed on 15 April 2017.

National People's Congress. 2013. The web site of the national people's congress 2013. URL: goo.gl/upY3im. Last ac- $\quad$ cessed on 16 December 2015.

Pavlou, P.A. 2003. Consumer acceptance of electronic commerce: Integrating trust and risk with the technology acceptance model. International Journal of Electronic Commerce, 7(3): 101-134. DOI: 10.4018/jeco.2003010102

Pavlou, P.A., \& Gefen, D. 2004. Building effective online marketplaces with institution-based trust. Information Systems Research, 15(1): 37-59. DOI: /10.1287/isre.1040.0015

Pennington, R., Wilcox, H.D., \& Grover, V. 2003. The role of system trust in business-to-consumer transactions. Journal of Management Information Systems, 20(3): 197-226. DOI: 10.1080/07421222.2003.11045777

$\mathrm{Su}, \mathrm{Z}$., Xie, E., \& Wang, D. 2015. Entrepreneurial orientation, managerial networking, and new venture performance in China. Journal of Small Business Management, 53(1): 228-248. DOI: 10.1111/jsbm.12069

Wagner, G., Schramm-Klein, H., \& Schu, M. 2016. Determinants and moderators of consumers' cross-border online shopping intentions. Marketing ZFP, 38(4): 214-227. DOI: 10.15358/0344-1369-2016-4-214

Yamamoto T., Ueda H., Takahashi, K., Ogasahara, M., Sekiya, N., Komuro, H., Nakamura, I., \& Hashimoto, Y. 2012. Comparison of the internet anxieties between the Americans and Japanese which use the result of a group interview. Groupware and Network Service, 84: 1-8.

Yamamoto, T., Chiba, N., Magata, F., Takahashi, K., Sekiya, N., Nakamura, I., Ogasahara, M., \& Hashimoto, Y. 2011. Investiga- $\quad$ tion on anxieties while using the internet to study about "Anshin". Journal of Information Processing, 19: 212-220. $\quad$ DOI: 10.2197/ipsjjip.19.212

— This article does not have any appendix. - 